\title{
The Relationship Between Financial Crisis and Energy Efficiency: A Sectoral Study in Turkey
}

\author{
Isil Sirin Selcuk $^{1} \&$ Serap Durusoy ${ }^{1}$ \\ ${ }^{1}$ Department of Economics, Bolu Abant Izzet Baysal University, Bolu, Turkey \\ Correspondence: Isil Sirin Selcuk, Department of Economics, Faculty of Economics and Administrative Sciences, \\ Bolu Abant İzzet Baysal University, Bolu, Turkey. Tel: 90-374-254-1000.
}

Received: July 10, 2019

Accepted: August 5, 2019

Online Published: September 26, 2019

doi:10.5430/rwe.v10n3p78

URL: https://doi.org/10.5430/rwe.v10n3p78

\begin{abstract}
Energy efficiency, which refers to services and output being produced with less energy input, has become an important issue in terms of increasing environmental performance, energy security and international competitiveness today. Sectoral energy efficiency directly affects energy consumption per output on one hand, and contributes positively to profitability through costs on the other. It results in a competitive advantage by enabling investments to be made at a lower cost compared to other sectors and shortening the break-even period of the investments. However, a decrease in cash flow due to difficult financing conditions created by the financial crisis, which emerged in the housing market in the US in 2008 and became a global crisis through the financial sector, affected the energy sector by creating a negative impact on energy demand and supply. The cancellation of projects due to lack of financing, reduction of oil supply and drilling operations of energy companies, and reductions in refined pipelines are examples of the problems experienced on the supply side. On the consumption side, equipment and device sales decreased. The effect of the financial crisis on energy efficiency will be examined in this study. Using the Logarithmic Mean Divisia Index Decomposition method, the causes of changes in energy intensity and energy use will be analyzed on a sectoral basis in Turkey. The aim of this study is to explain the sectoral changes caused by the financial crisis with the help of energy intensity measure based on an analysis conducted with current data.
\end{abstract}

Keywords: divisia index, energy intensity, financial crisis, energy policy

JEL Classification: Q40, G01

\section{Overview of the Financial Crisis}

In the 1980s, a movement that sought to bypass sovereign states and tried to solve every issue through market forces was imposed on many countries. In the 1990s, the transition to financial liberalization turned the world economy into a holistic and vulnerable structure. In fact, the debt crisis after 1980 was effective in the adoption of financial liberalization. (Toussaint, 1999, p.102) As a result of the significantly diminishing external financing opportunities caused by the debt crisis in the 1980s, developing countries changed the composition of private capital flows (in the form of external debt and commercial bank loans) to obtain the capital accumulation they needed in order to realize growth and development, and shifted to foreign capital (direct investment and portfolio) (Gibson and Tsakalatos, 1996, p.173-210; Esen, 1998, p.59). Through financial liberalization, governments removed the controls and restrictions on the banking financial system to attract the international financial activities of developed countries to their own countries, and economies were opened to international capital flows. (Ongun, 1997, p. 37-40) In other words, the preferences of capital with international mobility play a decisive role in economies (Wood, 2000, p.20; Saribay, 2004, p. 88).

As a matter of fact, the crisis that started in Taiwan in July 1997 and later influenced many Asian economies is a good example. In fact, this crisis deeply influenced Russia, Brazil, Turkey, Argentina and even Japan in the following year (Went, 2001, p.149-159). However, the financial crisis, which began in the USA in 2007 and shook the foundations of the world economic system, is important not only for observing that an unregulated market mechanism is a threat to developing countries, but also for demonstrating the effects of the bubble created by greed for profit on developed countries as well.

In particular, the securitization process itself was the beginning of the weak links that would trigger the crisis. It is known that US banks provided the necessary resources for housing loans by borrowing via bonds issued by investment banks. At this stage, "finance engineers" rated these securities classified according to their risk and return and graded these securities as "investable." In other words, the inadequacy of the commitment (mortgage) standards, unhealthy 
risk management, financial products with increasing complexity and loss of transparency, and the consequent excessive borrowing created a serious weakness in the whole system (Frankel \& Harpel, 2008; Kaminsky \& Schmukler, 2008).

Particularly, subprime and other risky borrowings, which caused the bubble in the housing sector, also rose (Bernanke et al., 2011). Although the indicators of the crisis go back to 2006, actual signs began to appear as Bear Stearns, an investment bank in the US, went bankrupt in August 2008. The collapse of giant US banks and investment funds, and the subsequent bailout of some of them by the US government, resulted in the most severe financial crisis since the Great Depression.

It could be noted that the crisis was not caused by the fact that the structural problems of developing countries were no longer sustainable, which was the case in previous crises. However, these countries had to face the consequences of the crisis although they were not the cause of it. This is because the crisis led to a significant shrinkage in cash flows and credit volumes in financial markets, which had become important with the globalization process, leading to a significant slowdown in growth resulting in stagnation. Primarily, the negative impact of the global crisis on world economies was initially seen in financial markets and capital movements. In the following months, the problem started to affect the real sector and domestic markets and the crisis took the world economy by storm by the end of 2008 (Lin, 2008).

With this crisis of global capitalism, the world and emerging economies including Turkey realized that they were far more dependent on the global economy and international trade than previously thought. In a sense, during the crisis countries were confronted with the fact that global capitalism transformed countries into an organic whole (Claessens \& Schmukler, 2007; Gozzi et al., 2008) and it revealed that the global system became unmanageable. It also indicated the relative decline of the economic, and subsequently political, domination of the West over the past 300 years.

On the other hand, the emerging crisis in the US mortgage markets evolved over a short period of time and affected all of Europe. European countries, especially Eurozone countries in the region such as Italy, Ireland, Portugal, and Spain suffered a rapid decline in growth rates, and the destructive crises in these countries began to be called the Euro Zone debt crisis. These economies fell into recession, and started to shrink due to the financial tightness between banks and the low level of liquidity in the economies. This was proven by inflation figures that had fallen to serious levels while the increase in unemployment rates accelerated due to the closure or bankruptcy of many businesses. Additionally, unforeseeable increases in public debt brought about economic instability, and countries drifted into a state of chaos and were brought to the edge of bankruptcy.

In fact, it could be noted that EU countries with high debt would have suffered a crisis even if the mortgage situation that triggered the debt crisis in the EU countries had not happened, but the mortgage crisis moved the possible financial crisis in EU countries with weaker macroeconomic structures to an earlier time frame. As a matter of fact, long-term and long-ignored structural problems played a major role in the EU debt crisis. The most prominent of these structural problems was the extremely high public and private sector debt ratios that could not be managed by national resources. Moreover, common structural problems, such as single-centered monetary policy but multi-centered fiscal policy, competitive disadvantages between countries due to economic differences, and the lack of necessary attention to the Maastricht criteria, which were put in place before the transition to common currency, can be listed among the causes of the crisis (Akçay, 2013, p.2; Sezgin, 2013, p.81).

As can be seen, the financial sector, which constitutes a significant part of capitalism, became the center of the crisis in both the USA and the EU. This has raised questions regarding the survival of global capitalism. At this point, we face the fact that the imbalance between the financial sector and the real sector must be eliminated (Gallino, 2007, p.87). The energy sector is undoubtedly the area where this can be seen most clearly.

\section{Global Financial Crisis and Energy Sector}

The global financial crisis has affected the energy sector as well as every other sector. The most important change in the energy sector after the crisis has been the rise of energy nationalism. Since energy is a strategic sector for the growth of a country, even governments that strongly advocated liberalization in all areas did not ignore the national concerns of the crisis when it came to the concrete steps to be taken in the post-crisis period.

Indeed, in the European Union, it was observed that Germany and France rejected the purchase demands for their own energy companies originating from within the EU, and spent a great effort for these companies to stay in national hands. Furthermore, the European Union Council's decision to implement anti-dumping tax on B-99 Biodiesel fuel imported from the United States was met with reaction by the US, the EU's largest trading partner and the world's largest economy. After a complaint by the European Biodiesel Association (which represents a large part of EU biodiesel production) that US biodiesel was sold very cheaply in the European market due to incentives and that it was even cheaper than the vegetable oil from which it was produced, the Council decided in 2008 to apply anti-dumping 
duties on these products ranging from 213-409 Euros per ton (IKV, 2009).

Conversely, the impacts of the crisis on energy suppliers in the energy sector can be evaluated in terms of negative and positive aspects. The most significant negative impact of the crisis on the energy sector is the decrease in investments made in the sector. As of September 2009, worldwide oil and natural gas exploration and production investments decreased by USD 100 billion compared to 2008 according to the IEA. Increasing capital costs, which make investments difficult due to low profitability, can be one reason for this decrease. This has been an important problem especially for the renewable energy industry, where investment costs are higher than in other energy sectors (Leviner, 2010). Another reason is the difficulty in finding credit and the increasing cost of borrowing. More significantly, banks have started to shorten the periods for loan repayment, with some allowing a maximum of only five years or less, which places the refinancing risk on the project sponsor (Fritz-Morgenthal et al., 2009, p.1). In this period, capital flows reduced the attractiveness of new investments and projects were cancelled due to reductions in cash flow (Leviner, 2010). Other reasons for the decreased investment can be listed as increased need for incentives, increase in debt/equity ratio caused by the depreciation of stocks due to the crisis, decreased risk appetite, and reduced demand for investment due to declining demand leading to low capacity requirements (IEA, 2009).

It can also be said that the decrease in energy investments, the delay in long-term political and economic measures to be taken for "sustainable development," and the interruption of climate change measures can create a danger for energy security in the future and can negatively affect the fight against climate change.

On the other hand, the crisis can be considered an opportunity for energy suppliers for the transition to clean energy (Lucon \& Goldemberg, 2009, p.123). As energy supplying countries need partners to share the high cost of energy projects, they can approach multinational corporations more positively. This in turn can create new opportunities for cooperation (NATO Review, 2009). The reduction in electricity consumption allows the re-planning of the energy field, and governments can create jobs by supporting the investment plans of these groups.

The period that started in the USA in 2008 and continued with the EU currency crisis has been a period of increasing governmental concern regarding energy security that has arisen with global climate change and fluctuations in energy prices, as well as a period where the financing of energy and the targets for transition to low-carbon economy have clashed with each other. While there is concern that financial crises can reduce welfare in three dimensions -social, economic, and environmental-, there may also be an opportunity for governments for transition to a low-carbon economy. The fundamental aspect of this transition is energy efficiency, which refers to less energy consumption per output.

The concept of energy efficiency has been on the agenda of the world and governments for a long time, and has especially started to gain impetus in the last decade. Today, energy efficiency has become an important issue in the design and application of energy policies around the world since energy efficiency applications have relatively low cost compared to renewable energy, and are easier to deploy and expand.

Table 1. Total global energy consumption, production and imports over the years

\begin{tabular}{llll}
\hline Years & $\begin{array}{l}\boldsymbol{\Delta} \text { Total } \\
\text { Consumption }\end{array}$ & $\begin{array}{l}\boldsymbol{\Delta} \text { Total } \\
\text { Production }\end{array}$ & $\boldsymbol{\Delta}$ Total Imports \\
\hline $\mathbf{2 0 0 4}$ & $5 \%$ & $5 \%$ & $7 \%$ \\
\hline $\mathbf{2 0 0 5}$ & $3 \%$ & $3 \%$ & $3 \%$ \\
\hline $\mathbf{2 0 0 6}$ & $3 \%$ & $3 \%$ & $3 \%$ \\
\hline $\mathbf{2 0 0 7}$ & $3 \%$ & $2 \%$ & $2 \%$ \\
\hline $\mathbf{2 0 0 8}$ & $1 \%$ & $2 \%$ & $1 \%$ \\
\hline $\mathbf{2 0 0 9}$ & $-1 \%$ & $-1 \%$ & $-2 \%$ \\
\hline $\mathbf{2 0 1 0}$ & $5 \%$ & $5 \%$ & $6 \%$ \\
\hline $\mathbf{2 0 1 1}$ & $2 \%$ & $3 \%$ & $3 \%$ \\
\hline $\mathbf{2 0 1 2}$ & $1 \%$ & $1 \%$ & $2 \%$ \\
\hline $\mathbf{2 0 1 3}$ & $2 \%$ & $1 \%$ & $1 \%$ \\
\hline $\mathbf{2 0 1 4}$ & $1 \%$ & $2 \%$ & $0 \%$ \\
\hline $\mathbf{2 0 1 5}$ & $1 \%$ & $1 \%$ & $3 \%$ \\
\hline $\mathbf{2 0 1 6}$ & $1 \%$ & $0 \%$ & $3 \%$ \\
\hline
\end{tabular}

Source: Prepared by the authors using IEA (2018) data. 
Globally, energy use and economic growth move together. Nevertheless, while gross domestic product (GDP) doubled between 1990 and 2016, total primary energy supply more than doubled and increased by 57\% in this period. (IEA, 2018). However, as shown in Table 1, with the global financial crisis in 2008, it is possible to observe a decrease in energy consumption in the world. A similar decrease was observed in consumption, production and imports after the European debt crisis in 2013.

The global financial crisis has also caused a slowdown in the positive steps taken in the field of energy efficiency in many parts of the world. According to World Energy Council research, primary energy intensity is decreasing in all regions around the world except the Middle East. Although the global economic crisis has had a strong impact on the improvement in energy efficiency in most regions except Asia and Europe since 2008, energy intensity has decreased less since 2008. This means a decrease from $1.6 \%$ per year between 2000 and 2008 to $1.3 \%$ per year since 2008 (World Energy Council, 2016, p. 21). Therefore, it is possible to say that since 2008, there has been a clear slowdown in the decrease of energy intensity in most regions and at the global level.

\section{Sectoral Energy Efficiency in Turkey and Its Relationship With Financial Crises}

Although it serves as an energy corridor due to its location, Turkey is an energy importer and a foreign-dependent country for energy supply due to its increasing energy demand. When sectoral level energy use is examined, according to data from the International Energy Agency, energy consumption of the three sectors are noteworthy, just as in the world. These sectors are industry, transportation and households respectively. In particular, energy use in the transportation sector has increased significantly since 2012. However, in 2008, 2009 and 2013, which were the years of crisis, there was a decrease of energy consumption in almost every sectors and thus total energy use (Figure 1).

The importance of energy efficiency increases day by day for Turkey in order to balance energy consumption and ensure energy security. Likewise, energy efficiency is highly important in reducing the dependency on fossil fuels for primary energy use and for increasing energy efficiency in combating global warming. In this respect, Turkey has frequently emphasized the concept of energy efficiency in its official policies, especially in recent years.

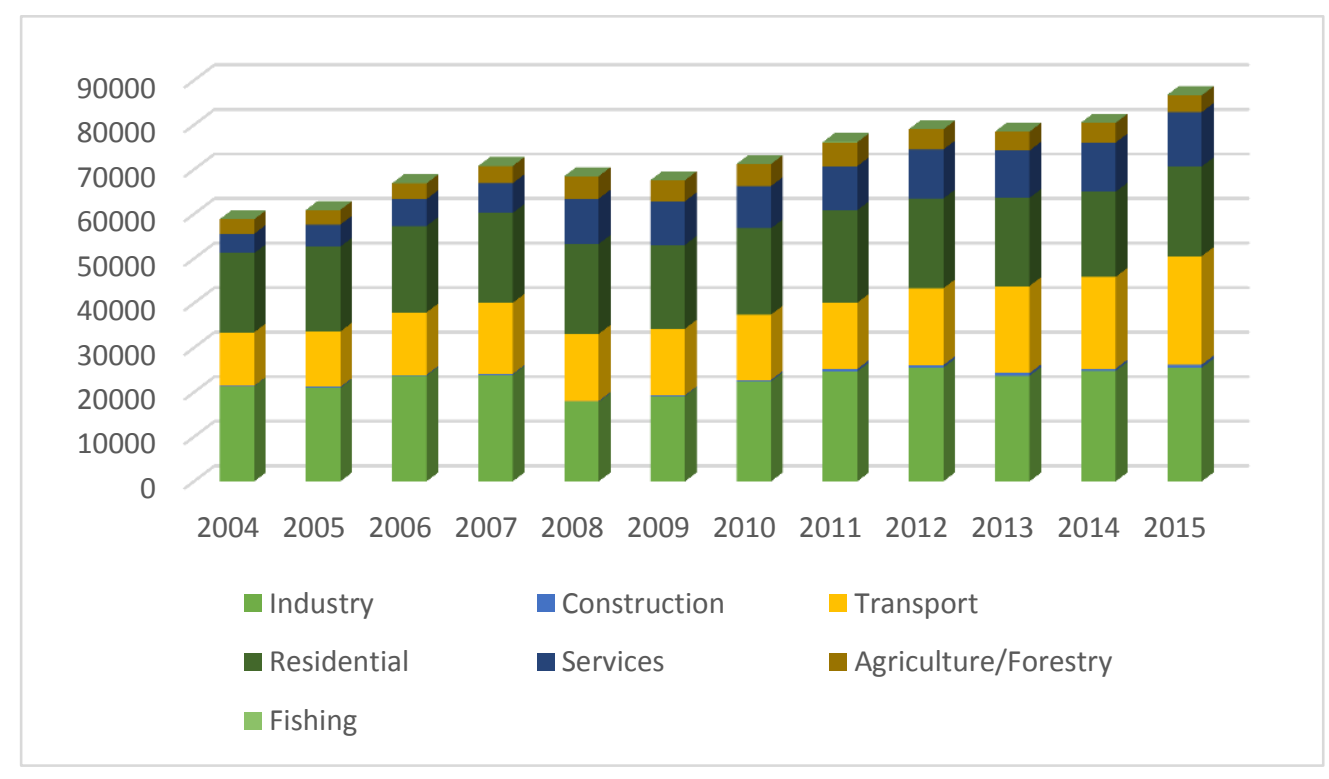

Figure 1. Total energy consumption by sectors (ktoe)

Source: Prepared by the authors using IEA (2018) database.

The energy efficiency Law No. 5627, which was enacted in 2007, is extremely important in this regard. The Energy Efficiency Coordination Board was established with the aim of ensuring the efficient operation of energy efficiency activities throughout the country by related institutions, coordinating these activities, and monitoring the results. In addition, 2008 was declared the Year of Energy Efficiency. The Energy Efficiency Strategy Document, prepared in 2012, stated that Turkey aimed to reduce its energy consumption by at least 20\% compared to 2011 levels by 2023 . 
The National Energy Efficiency Action Plan, covering the period 2017-2023, aims to reduce Turkey's primary energy consumption by $14 \%$ by 2023 through 55 actions specified for six sectors including agriculture, technology, energy, transport, industry, buildings and services.

In this study, by using the concept of energy intensity, sectoral and total changes of energy efficiency will be examined. Energy intensity is defined as the ratio between the total energy consumption measured in tonnes of oil equivalent (toe) and the indicators of economic activity measured in real currency (value added).

\section{Data and Method}

Sectoral level energy intensity will be calculated using data from the years 2003-2016 for Turkey. Sectoral energy consumption data were obtained from the International Energy Agency database. Sectoral output data are taken from the Turkish Statistical Institute. In the data set, energy consumption is expressed in terms of energy, in kiloton equivalent oil (ktoe), while sectoral output is measured with real added value. The data set had to be limited to the industry, construction, transportation and services sectors due to the lack of data for TurkStat's agriculture/ forestry, household and fishing subsectors.

In this study, the extended LMDI decomposition analysis method developed by Choi and Ang (2012) will be used to observe the contribution of the sub-sectors to the industrial energy intensity of Turkey. However, the total energy intensity of the sector will be determined by the LMDI decomposition analysis method proposed by Ang (1994) before finding the contribution of the sub-sectors. At this point, the change in energy intensity will be calculated for both single-period and multi-period and will be separated into two as structural effect and real energy intensity effect.

To digress, the LMDI decomposition analysis method has two separate interpretations, called Montgomery-Vartia or LMDI-I and Sato-Vartia or LMDI-II, depending on the weight function. In this study, the Sato-Vartia approach, also called LMDI-II, will be utilized. The main reason for this is that the geometric mean is required for extended analysis. For LMDI-I, although the sum of the weights of the index is close to one, it may not always be equal to one, therefore it cannot be called a true geometric mean. This problem does not exist for the LMDI-II index, and therefore, it was preferred in this application. The abbreviations used in the decomposition analysis following the method of Choi and Ang (2012) are shown in Table 2.

Table 2. Abbreviations used in index decomposition analysis

\begin{tabular}{ll}
\hline $\mathbf{E}$ & Total Energy Consumption \\
\hline $\mathbf{Y}$ & Total Sectoral Production \\
\hline $\mathbf{I}$ & Total Energy Intensity (E/Y) \\
\hline $\mathbf{R}$ & Real Energy Intensity Impact Indicator \\
\hline $\mathbf{S}$ & Indicator to Measure the Effect of Structural Change of the Sector \\
\hline
\end{tabular}

In the case of $\mathrm{N}$ industry sub-sectors, let $\mathrm{E}$ denote total industrial energy use and $\mathrm{Y}$ denote total industrial production. Then, Ei and Yi respectively refer to energy consumption for the sector i and production for the sector i. In this case, total energy intensity for the industrial sector is $\mathrm{E} / \mathrm{Y}$, and the energy intensity for sector i is Ei/Yi. Similarly, the output share of the sector $\mathrm{i}$ is $\mathrm{Si}=\mathrm{Yi} / \mathrm{Y}$. Then, total energy intensity can be written as follows:

$$
I=\sum_{i=1}^{N} \frac{E_{i}}{Y_{i}} \frac{Y_{i}}{Y}=\sum_{i=1}^{N} I_{i} S_{i}
$$

According to Divisia decomposition, the single-term change in total energy intensity can be written in its most general form as a function of real energy intensity index and structural change index, as follows:

$$
\frac{I_{t}}{I_{0}}=\frac{R_{t}}{R_{0}} \frac{S_{t}}{S_{0}}
$$

To achieve this general form; first, equation (3) can be reached when the derivative of equation (1) is taken.

$$
\frac{d I}{d t}=\sum_{i=1}^{n} S_{i} \frac{d I_{i}}{d t}+\sum_{i=1}^{n} I_{i} \frac{d S_{i}}{d t}
$$


If we divide both sides by I and define the variable $w_{i}$ as the energy consumption share of sector $\mathrm{i}$;

$$
\frac{d \ln I}{d t}=\sum_{i=1}^{n} w_{i} \frac{d \ln I_{i}}{d t}+\sum_{i=1}^{n} w_{i} \frac{d \ln S_{i}}{d t} ; \quad w_{i}=\frac{I_{i} S_{i}}{I}=\frac{E_{i}}{E}
$$

it is then possible to obtain equation (5) when we take the integral of both sides at a range of [0, t] and make use of the mean value theorem.

$$
\frac{I_{t}}{I_{0}}=\exp \left(\sum_{i=1}^{n} w_{i}^{*} \ln \frac{I_{i, t}}{I_{i, 0}}\right) \exp \left(\sum_{i=1}^{n} w_{i}^{*} \ln \frac{S_{i, t}}{S_{i, 0}}\right) ; w_{i}^{*} \equiv w_{i}\left(t_{i}, w\right) v e\left(t_{i}, w\right) \in[0, t]
$$

In this case, the first part on the right side of the equation will allow us to calculate the effect of energy intensity, the second part will allow us to calculate the effect of structural change, and the two will give us the change in total energy intensity. It is possible to calculate the right side of the equation with the help of a suitable weight function. So, instead of $w_{i}^{*}$, if we weight the logarithmic average function proposed by Ang and Choi (1997) using the Sato-Vartia index, we can obtain the following equation.

$$
\frac{I_{t}}{I_{0}}=\exp \left(\sum_{i=1}^{n} \frac{L\left(E_{i, t} / E_{0}, E_{i, 0} / E_{0}\right)}{\sum_{i=1}^{n} L\left(E_{i, t} / E_{0}, E_{i, 0} / E_{0}\right)} \ln \frac{I_{i, t}}{I_{i, 0}}\right) \exp \left(\sum_{i=1}^{n} \frac{L\left(E_{i, t} / E_{0}, E_{i, 0} / E_{0}\right)}{\sum_{i=1}^{n} L\left(E_{i, t} / E_{0}, E_{i, 0} / E_{0}\right)} \ln \frac{S_{i, t}}{S_{i, 0}}\right)
$$

The first part on the right side of the equation gives the effect of real energy intensity $\left(\frac{R_{t}}{R_{0}}\right)$, while the second part gives the structural effect $\left(\frac{S_{t}}{S_{0}}\right)$. Thus, it is possible to obtain a single-period change in total energy intensity indicated above in its general form.

The change in energy intensity for multiple periods, rather than a single period, can be calculated by the cumulative multiplication of the single-period decomposed indices. In this case, the formula for multiple periods will be as in equation (7).

$$
\frac{I_{t}}{I_{0}}=\prod_{t=1}^{T} \frac{I_{t}}{I_{t-1}}=\prod_{t=1}^{T}\left(\frac{R_{t}}{R_{t-1}} \frac{S_{t}}{S_{t-1}}\right)
$$

For the extended LMDI analysis proposed by Choi and Ang (2012), it is necessary to first convert the geometric mean index to the arithmetic mean index. The logarithmic change form of the Divisia real energy index can be written as a geometric mean index as follows:

$$
\ln \frac{R_{t}}{R_{0}}=\sum_{i=1}^{n} w_{i} \ln \frac{I_{i, t}}{I_{i, 0}} \Leftrightarrow \frac{R_{t}}{R_{0}}=\prod_{i=1}^{n}\left(\frac{I_{i, t}}{I_{i, 0}}\right)^{w_{i}}
$$

If unknown variables are expressed as $\phi_{i}$, the geometric index can be converted to the arithmetic mean index as shown in equation (9).

$$
\frac{R_{t}}{R_{0}}=\frac{\sum_{i=1}^{n} \phi_{i} I_{i, t}}{\sum_{i=1}^{n} \phi_{i} I_{i, 0}}
$$

If we would like to define $s_{i, 0}$ and $s_{i, t}$ from the right side of the equation, they can also be represented by the following equivalence:

$$
S_{i, 0} \equiv \frac{\phi_{i} I_{i, 0}}{\sum_{j=1}^{k} \phi_{j} I_{j, 0}}, s_{i, t} \equiv \frac{\phi_{i} I_{i, t}}{\sum_{j=1}^{k} \phi_{j} I_{j, t}}
$$

Using the logarithmic mean definition and $\sum_{i=1}^{n}\left(s_{i, t}-s_{i, 0}\right)=0$, the following two equivalences are obtained according to Balk (2004). 


$$
\begin{gathered}
\sum_{i=1}^{n} L\left(s_{i, t}, s_{i, 0}\right) \ln \left(\frac{s_{i, t}}{s_{i, 0}}\right)=0 \\
\ln \left(\frac{s_{i, t}}{s_{i, 0}}\right)=\ln \left(\frac{I_{i, t}}{I_{i, 0}}\right)-\ln \left(\frac{R_{t}}{R_{0}}\right)
\end{gathered}
$$

Equation (12) is placed in equation (11) and solved for $\frac{R_{t}}{R_{0}}$, a new conversion formula for $\frac{R_{t}}{R_{0}}$ is obtained. This formula is shown in equation (13).

$$
\ln \left(\frac{R_{t}}{R_{0}}\right)=\sum_{i=1}^{n} \frac{L\left(s_{i, t}, s_{i, 0}\right)}{\sum_{j=1}^{k} L\left(s_{j, t}, s_{j, 0}\right)} \ln \left(\frac{I_{i, t}}{I_{i, 0}}\right)=\sum_{i=1}^{n} \frac{\phi_{i} L\left(I_{i, t}, I_{i, 0}\left(\frac{R_{t}}{R_{0}}\right)\right)}{\sum_{j=1}^{k} \phi_{j} L\left(I_{j, t}, I_{j, 0}\left(\frac{R_{t}}{R_{0}}\right)\right)} \ln \left(\frac{I_{i, t}}{I_{i, 0}}\right)
$$

It is possible to find $\phi_{i}$ containing unknown variables by comparing equations (8) and (13) giving the logarithmic change function.

$$
\phi_{i}=\frac{w_{i}}{L\left(I_{i, t}, I_{i, 0}\left(\frac{R_{t}}{R_{0}}\right)\right)}
$$

If equation (14) is placed in equation (13) and total wi is equal to one, then it is seen that the right side of equation (13) and equation (8) in the logarithmic change form are the same. Choi and Ang (2012) called equation (14) the "Reinsdorf Formula". This formula provides a link between the geometric mean index and the arithmetic mean index. Then, it is possible to write the extended formula of LMDI as follows:

$$
\left(\frac{R_{t}}{R_{0}}-1\right)=\sum_{i=1}^{n} s_{i}\left(\frac{I_{i, t}}{I_{i, 0}}-1\right) ; s_{i}=\frac{\phi_{i} I_{i, 0}}{\sum_{j=1}^{k} \phi_{k} I_{k, 0}}=\frac{\frac{w_{i}}{L\left(I_{i, t}, I_{i, 0}\left(\frac{R_{t}}{R_{0}}\right)\right)} I_{i, 0}}{\sum_{j=1}^{k} \frac{w_{k}}{L\left(I_{j, t}, I_{j, 0}\left(\frac{R_{t}}{R_{0}}\right)\right)} I_{j, 0}}
$$

For multi-period, as in the LMDI decomposition analysis, the chain real energy intensity index can be used. According to this:

Thus, the multi-period formula is the cumulative sum of the single-period percentage change for the time interval [t-1, t] multiplied by $\frac{R_{t-1}}{R_{0}}$. Thus, if equation (15) obtained for the single period is placed in equation (16), the multi-period expanded logarithmic mean Divisia chain index can be obtained as in equation (17).

$$
\begin{aligned}
& \left(\frac{R_{t}}{R_{0}}-1\right)=\sum_{i=1}^{n} \sum_{t=1}^{T} \frac{R_{t-1}}{R_{0}} s_{i, t-1 . t}\left(\frac{I_{i, t}}{I_{i, t-1}}-1\right) \\
& s_{i, t-1 . t}=\frac{\frac{w_{i}, t-1, t}{L\left(I_{i, t}, I_{i, t-1}\left(\frac{R_{t}}{R_{t-1}}\right)\right)} I_{i, t-1}}{\sum_{j=1}^{k} \frac{w_{k, t-1, t}}{L\left(I_{j, t}, I_{j, t-1}\left(\frac{R_{t}}{R_{t-1}}\right)\right)} I_{k, t-1}}
\end{aligned}
$$

This approach takes part in the literature. Gonzalez et al. (2013) found the contribution of each sector by calculating the total energy intensity between 1995 and 2010 for 20 European countries. Voigt et al. (2014) examine energy intensity 
trends in 40 major economies both using LMDI and attribution analysis. Choi and Oh (2014) used the extended Divisia decomposition analysis method for the Korean manufacturing industry and calculated the contribution of ten sub-sectors to the real energy intensity of the manufacturing industry. Andres and Padilla (2015) used this method to analyze road freight transport of heavy goods vehicles and the factors that have influenced the Spanish energy intensity trend. In addition, Timma et al. (2015) and Balezentis et al. (2011) examined the correlation between the energy sector and the global financial crisis for Latvia and Lithuania, respectively, by using the LMDI method. In their study, Balezentis et al. (2011) emphasized that energy efficiency decreased during periods of economic collapse.

\section{Results}

When the data were analyzed, the total real added value of the four sectors, namely industry, construction, transportation and services increased by $70 \%$ between 2003 and 2015, and in parallel with this increase, the total energy consumption (E) of the four sectors increased by $70 \%$. Conversely, total energy intensity (E / Y) increased slightly in 2015 compared to 2003, but no remarkable change was observed in 2015 . However, this result should not cover the fluctuation in energy intensity. For a single-period (reference year is the previous year) and for multiple-period (starting from 2003) decomposition results obtained by decomposing total energy intensity are given in Table 3. The fall in the total energy intensity index in the table means an increase in energy efficiency.

Table 3. Change in total energy intensity according to LMDi decomposition analysis

\begin{tabular}{lllllll}
\hline & \multicolumn{2}{l}{ Single Period (Base Year=2003) } & \multicolumn{3}{l}{ Multi Period (Base Year=Previous Year) } \\
\hline Years & $\begin{array}{l}\text { Real Energy } \\
\text { Intensity } \\
\text { Effect }\end{array}$ & $\begin{array}{l}\text { Structural } \\
\text { Effect }\end{array}$ & $\begin{array}{l}\text { Total } \\
\text { Energy } \\
\text { Intensity }\end{array}$ & $\begin{array}{l}\text { Real Energy } \\
\text { Intensity } \\
\text { Effect }\end{array}$ & $\begin{array}{l}\text { Structural } \\
\text { Effect }\end{array}$ & $\begin{array}{l}\text { Total Energy } \\
\text { Intensity }\end{array}$ \\
\hline 2003 & 1.000 & 1.000 & 1.000 & 1.000 & 1.000 & 1.000 \\
\hline 2004 & 0.938 & 0.986 & 0.925 & 0.938 & 0.986 & 0.925 \\
\hline 2005 & 1.136 & 0.912 & 1.035 & 1.065 & 0.899 & 0.958 \\
\hline 2006 & 1.058 & 1.013 & 1.072 & 1.126 & 0.911 & 1.026 \\
\hline 2007 & 1.023 & 1.032 & 1.056 & 1.153 & 0.940 & 1.084 \\
\hline 2008 & 0.881 & 0.998 & 0.879 & 1.015 & 0.938 & 0.952 \\
\hline 2009 & 1.150 & 0.998 & 1.148 & 1.168 & 0.936 & 1.093 \\
\hline 2010 & 1.092 & 0.942 & 1.029 & 1.276 & 0.882 & 1.126 \\
\hline 2011 & 0.944 & 0.968 & 0.914 & 1.204 & 0.854 & 1.028 \\
\hline 2012 & 1.004 & 1.064 & 1.069 & 1.209 & 0.909 & 1.099 \\
\hline 2013 & 0.897 & 1.010 & 0.906 & 1.085 & 0.918 & 0.995 \\
\hline 2014 & 1.070 & 0.950 & 1.017 & 1.161 & 0.872 & 1.012 \\
\hline 2015 & 0.916 & 1.082 & 0.991 & 1.063 & 0.943 & 1.002 \\
\hline
\end{tabular}

When Table 3 is examined, one of the first remarkable findings is the rapid decrease in total energy intensity in 2008, both in the single and multiple periods, due to either the impact of the energy efficiency law in 2007, or the impact of the first year of the global crisis.

This decrease was not limited to only the year 2008. Similarly, a decrease in total energy intensity was seen in 2013. While the reason for the decrease in 2008 was the recession caused by the mortgage crisis, the decrease in total energy intensity in 2013 could be attributed to the recession caused by the European Union debt crisis, since energy intensity is not following a trend but only decreasing in certain years.

The fall in energy efficiency in 2009, when investments in the energy sector decreased compared to 2003, shows parallelism with global trends. Declining energy efficiency since 2009 only increased in 2013 compared to 2003. 
When it is analyzed based on the sector and compared to the previous year, the decrease in energy efficiency seen in 2009 and 2014 immediately after the increase in 2008 and 2013 is another result shown in the table. The main reason for the sharp decline occurring in 2008 was the increase in the value added for this year, while the energy use of the industrial sector decreased. Thus, the energy used per value-added has decreased significantly. The decline in total energy intensity in 2008 and 2013 is due to the recession in the industrial sector, and therefore, the decrease in total energy intensity in the industrial sector. In 2013, a decrease was experienced in energy intensity in the service sector in addition to industry over the previous year.

Table 4. Attribution results for LMDI Analysis (In percentage)

\begin{tabular}{lllllllllll}
\hline \multicolumn{3}{l}{ Single Period (Base Year=2003) } & \multicolumn{5}{c}{ Multi Period (Base Year=Previous Year) } \\
\hline Years & Industry & Construction & Transport & Services & Total & Industry & Construction & Transport & Services & Total \\
\hline 2004 & $-4,311$ & -0.036 & -1.997 & 0.139 & -7.514 & -4.311 & -0.036 & -1.997 & 0.139 & -7.514 \\
\hline 2005 & 10.766 & 0.253 & 1.779 & 0.185 & 3.547 & 5.783 & 0.202 & -0.329 & 0.312 & -4.188 \\
\hline 2006 & -2.151 & -0.112 & 4.985 & 3.100 & 7.160 & 3.492 & 0.082 & 4.980 & 3.613 & 3.437 \\
\hline 2007 & 2.548 & -0.044 & -1.158 & 1.022 & 5.611 & 6.363 & 0.032 & 3.676 & 4.764 & 9.757 \\
\hline 2008 & -16.097 & -0.075 & -2.737 & 6.916 & -12.137 & -12.193 & -0.054 & 0.522 & 12.736 & -4.232 \\
\hline 2009 & 10.132 & 0.003 & 3.252 & 1.655 & 14.827 & -1.907 & -0.052 & 3.823 & 14.415 & 10.820 \\
\hline 2010 & 3.608 & 0.312 & 6.377 & -1.324 & 2.937 & 2.307 & 0.313 & 11.272 & 12.869 & 14.250 \\
\hline 2011 & -5.249 & 0.283 & 0.782 & -1.350 & -8.643 & -4.390 & 0.674 & 12.270 & 11.147 & 3.223 \\
\hline 2012 & 3.352 & 0.070 & -4.270 & 1.267 & 6.863 & -0.353 & 0.758 & 7.128 & 12.672 & 11.486 \\
\hline 2013 & -8.909 & 0.015 & 0.865 & -2.321 & -9.436 & -11.124 & 0.777 & 8.173 & 9.866 & 0.079 \\
\hline 2014 & 0.348 & -0.184 & 6.687 & 0.018 & 1.692 & -10.747 & 0.577 & 15.425 & 9.886 & 1.914 \\
\hline 2015 & -3.971 & 0.153 & -5.661 & 0.695 & -0.943 & -15.356 & 0.755 & 8.853 & 10.693 & 0.819 \\
\hline
\end{tabular}

If Table 4 is examined, another expected result is that the industrial sector, one of the highest energy consuming sectors, has a significant effect on the total energy intensity. In the industrial sector, both the crisis and energy efficiency policies partially reduced the energy intensity compared to 2003, i.e. energy efficiency increased. When the results are examined carefully, it is observed that there is a serious energy efficiency problem in the service and transportation sectors compared to 2003, since the energy intensity index showing the amount of energy used per output tends to increase compared to 2003.

\section{Conclusion}

A decrease in total energy intensity was observed in 2008 and 2013. While the decrease in 2008 was due to the recession caused by the mortgage crisis, the decrease in total energy intensity in 2013 can be associated with the impact of the recession caused by the EU debt crisis. When analyzed on a sectoral basis, the decrease in total energy intensity in 2008 and 2013 is mainly due to the stagnation in the industrial sector and thus to the decrease in the total energy intensity of the industrial sector.

Energy efficiency is a phenomenon of extreme potential and it can be realized quickly. On the path to energy sustainability, efficiency, which is the most inexpensive and readily available resource, should come first. However, in this study it was observed that the energy used per output, especially in the industrial sector, decreased due to the impact of crises in addition to the fragility of Turkey's economy and external economic effects. In fact, if this decrease was observed as a continuous decrease dependent on energy policies, then it would be possible to assume that energy efficiency policies had succeeded. However, the fact that the reduction was limited to the years 2008 and 2013, and that these were crisis periods, demonstrate that the desired level of energy efficiency could not be reached. The results show that effective policies and measures are needed for energy demanding sectors after economic slowdown years.

The transportation sector, which is an energy intensive sector, needs more attention from policy makers due to its 
contribution to the increase in energy intensity after the crisis years, as well as its increasing contribution to overall energy intensity. Another problematic area is the service sector; focusing solely on energy efficiency in industry does not seemingly help to achieve energy efficiency goals. Governments should consider measures such as promoting the use of hybrid and electric vehicles and making public transport preferable. When compared to 2003, the increase in the energy intensity in the service sector reminds us of the importance of a trained workforce and public awareness. Therefore, policymakers need to enhance current energy efficiency policies for the industrial sector, which consumes the most energy, as well as for other sectors.

\section{References}

Akçay, B. (2013). Avro Bölgesi Borç Krizi: GIIPS, Ekonomik Yaklaşım Dergisi, Gazi Üniversitesi, 23, 1-38. https://doi.org/10.5455/ey.34104

Andres, L., \& Padilla, E. (2015). Energy intensity in road freight transport of heavy goods vehicles in Spain. Energy Policy, 85, 309-321. https://doi.org/10.1016/j.enpol.2015.06.018

Ang, B. W. (1994). Decomposition of Industrial Energy Consumption: The Energy Intensity Approach. Energy Economics, 163-174. https://doi.org/10.1016/0140-9883(94)90030-2

Ang, B. W., \& Choi, K.-H. (1997). Decomposition of Aggregate Energy and Gas Emission Intensities for Industry: A Refined Divisia Index Method. The Energy Journal, 59-73. https://doi.org/10.5547/ISSN0195-6574-EJ-Vol18-No3-3

Balezentis, A., Balezentis, T., \& Streimikiene, D. (2011). The Energy Intensity in Lithuania during 1995-2009: A LMDI Approach. Energy Policy, 39, 7322-733. https://doi.org/10.1016/j.enpol.2011.08.055

Balk, B. M. (2004). Decompositions of Fisher Indexes. Economics Letters, 82, 107-113. https://doi.org/10.1016/j.econlet.2003.09.006

Bernanke, B. S., Bertaut, C., DeMarco, L. P., \& Kamin, S. (2011). International Capital Flow and the Returns to Safe Assets in the United States, 2003-2007. Board of Governors of the Federal Reserve System International Finance Discussion Papers, 1014. https://doi.org/10.17016/IFDP.2010.1014

Choi, K.-H., \& Ang, B. W. (2012). Attribution of changes in Divisia real energy intensity index: An Extension to index decomposition analysis. Energy Economics, 171-176. https://doi.org/10.1016/j.eneco.2011.04.011

Choi, K.-H., \& Oh, W. (2014). Extended Divisia Index Decomposition of Changes in Energy Intensity: A Case of Korean Manufacturing Industry. Energy Policy, 275-283. https://doi.org/10.1016/j.enpol.2013.09.031

Claessens, S., \& Schmukler, S. (2007). International Financial Integration Through Equity Markets: Which Firms from Which Countries Go Global?. CEPR Discussion Paper No. DP6137. https://doi.org/10.1596/1813-9450-4146

Esen, O. (1998). Finansal Küreselleşme Ortamında Gelişmekte Olan Ülkelere Yönelik Pörtföy Yatırımları. Ekonomik Yaklaşım, Gazi Üniversitesi Dergisi, 9, 59.

Frankel, J., \& Harpel, J. W. (2008). Retrieved June 2, 2019, from https://topics.blogs.nytimes.com/2008/12/26/origins-of-the-economic-crisis-in-one-chart/

Fritz-Morgenthal, S., Greenwood, C., Menzel, C., Mironjuk, M., \& Sonntag-O’Brien, V. (2009). The Global Financial Crisis and its Impact on Renewable Energy Finance. Paris: United Nations Environment Program, April 2009.

Gallino, L. (2007). Küreselleşme ve Eşitsizlik, (Kundakçı, D. Trans.). Ankara: Dost Kitapevi.

Gibson, H., \& Tsakalatos, E. (1996). Uluslararası Borç Krizi Sorunları Nedenler ve Çözümler, (Eds. Şenses, F.). Kalkınma İktisadı, İstanbul: İletişim Yayınları.

General Directorate of Law and Legislation of Turkey. (2019). Official Web Site. Retrieved May 6, 2019, from www.mevzuat.gov.tr

Gonzalez, P. F., Landajo, M., \& Presno, M. J. (2013). The Divisia real energy intensity indices: Evolution and attribution of percent changes in 20 European countries from 1995 to 2010. Energy, 340-349. https://doi.org/10.1016/j.energy.2013.06.013

Gozzi, J. C., Levine, R., \& Schmukler, S. (2008). Patterns of International Capital Raisings. Policy Research Working Paper 4687, World Bank, Washington, DC. https://doi.org/10.1596/1813-9450-4687

IEA. (2009). The Impact of the Financial and Economic Crisis on Global Energy Investment. IEA Background paper for the G8 Energy Ministers Meeting, 24-25 May 2009. 
IEA. (2018). World Energy Balances. Paris: OECD/IEA.

IEA Database. (2018). Energy Statistics of OECD countries: Beyond 2020 Documentation. OECD/IEA.

IKV. (2009). İktisadi Kalkınma Vakfı E-Bülteni. Retrieved June 2, 2019, from https://bulten.ikv.org.tr/?ust_id=3923\&id=3942

Kaminsky, G., Lyons, R., \& Schmukler, S. (2004). Managers, Investors, and Crises: Mutual Fund Strategies in Emerging Markets. Journal of International Economics, 64(1), $113-34$. https://doi.org/10.1016/S0022-1996(03)00075-8

Leviner, C. (2010). The Financial Crisis and Its Impact on European Energy Security of Supply. Paris Innovation $\begin{array}{lllll}\text { Review. } & \text { Retrieved } & \text { August } & 18, & 2019,\end{array}$ http://parisinnovationreview.com/articles-en/the-financial-crisis-and-its-impact-on-european-energy-security-ofsupply

Lin, J. (2008). The Impact of the Financial Crisis on Developing Countries. Paper presented at the Korea Development Institute, Seoul, 31 October. https://doi.org/10.1596/26129

Lucon, O., \& Goldemberg, J. (2009). Financial Crisis, Energy and Sustainability in Brazil. Estudos Avançados, 23(65), 121-130. https://doi.org/10.1590/S0103-40142009000100009

NATO Review. (2009). World Financial Crises: What It Means for Security. Retrieved June 1, 2019, from https://www.nato.int/docu/review/2009/FinancialCrisis/Energy-Security-Cooperation/EN/index.htm

Ongun, O. T. (1997). Finansal Küreselleşme, Ekonomik Yaklaşım. Gazi Üniversitesi, 4(9).

Sarıbay, A. Y. (2004). Modernitenin İronisi Olarak Globalleşme, Everest Yayınları, İstanbul.

Timma, L., Zoss, T., \& Blumberga, D. (2015). Life after the financial crisis: Energy intensity and energy use decomposition on sectorial level in Latvia. Applied Energy. https://doi.org/10.1016/j.apenergy.2015.04.021

Toussaint, E. (1999). Ya Paranı Ya Canını: Dünya Bankası ve IMF in Üçüncü Dünya Politikaları, (Berberyan, M. Trans.). İstanbul: Yazın Yayıncilık

Turkish Statistical Institute. (2018). Annual Industry and Service Statistics. Retrieved November 2, 2018, from http://www.turkstat.gov.tr/PreTablo.do?alt_id=1035

Voigt, S., De Cian, E., Schymura, M., \& Verdolini, E. (2014). Energy Intensity Developments in 40 Major Economies: Structural Change or Technology Improvement?. Energy Economics, 41, 47-62. https://doi.org/10.1016/j.eneco.2013.10.015

Went, R. (2001). Küreselleşme: Neo-Liberal İddialar Radikal Yanıtlar, (Dinç, E. Trans.). Yazın Yayıncılık, İstanbul.

Wood, E. M. (2000). Küresel Kapitalizm ve Ulus Devlet, (Eds. Kafaoğlu, A.B.). li Yıllara Girerken Kapitalizm, Kaynak Yayınları, İstanbul.

World Energy Council. (2016). World Energy Perspectives Energy Efficiency: A Straight Path Towards Energy Sustainability. London: WEC in partnership with ADEME. 